\title{
KILKA UWAG O NAZWISKU FIRADZA
}

\author{
Renata Marciniak-Firadza \\ Uniwersytet Łódzki \\ ORCID 0000-0001-6301-8820
}

\begin{abstract}
Streszczenie. Tematem artykułu jest rzadkie, obcobrzmiące, niedające się jednoznacznie objaśnić nazwisko Firadza. Celem artykułu jest przedstawienie stratygrafii chronologicznej i geograficznej nazwiska oraz zaprezentowanie kilku odmiennych stanowisk dotyczących jego etymologii. Omawiane nazwisko nie było dotychczas przedmiotem analiz onomastycznych, w tym antroponimicznych.
\end{abstract}

Slowa klucze: onomastyka, antroponimia, nazwisko

\section{WSTEP}

Jak podkreśla Józef Bubak, „Sporo już dziś wiemy o pochodzeniu polskich nazwisk, a literatura na ten temat jest wcale bogata. Mimo to nie każde nazwisko spotkane dziś w Polsce daje się jednoznacznie objaśnić, jeśli nie dysponujemy jego historycznymi zaświadczeniami"'. Do takich nazwisk, o których pisze Józef Bubak, należy niewątpliwie nazwisko Firadza. Nie było ono do tej pory przedmiotem analiz onomastycznych, $w$ tym antroponimicznych.

Celem artykułu jest przedstawienie stratygrafii chronologicznej i geograficznej nazwiska oraz jego etymologii.

\section{STRATYGRAFIA CHRONOLOGICZNA I GEOGRAFICZNA NAZWISKA FIRADZA}

Kwerenda dokumentów w Archiwum Państwowym w Łodzi pokazała, że najstarsze dane o nazwisku Firadza pochodzą z roku 1852. W tym roku

1 J. Bubak, Pochodzenie polskiego nazwiska Uryga, „Onomastica” 1989, t. 33, s. 209. 
w parafii Nowe gm. Krośniewice, pow. kutnowski, woj. łódzkie, przyszedł na świat Stanisław Firadza (akt urodzenia 46).

Interesujące dane na temat lokalizacji nazwiska Firadza w XIX wieku i do lat 20. XX wieku odnajdujemy na stronie www.geneteka.genealodzy.pl. $\mathrm{Z}$ akt urodzeń, małżeństw i zgonów z całej Polski wynika, że nazwisko to nosiło wówczas 27 osób zamieszkujących trzy parafie w województwie łódzkim, tj. Nowe, Grochów i Krośniewice (parafie te położone są w pow. kutnowskim, Nowe i Krośniewice w gm. Krośniewice, Grochów w sąsiedniej gminie Nowe Ostrowy) oraz 2 osoby zamieszkujące jedną parafię w województwie wielkopolskim, tj. Rdutów (gm. Chodów)². Również wyłącznie na obszarze północno-zachodniej części województwa łódzkiego (pow. łęczycki i kutnowski) oraz wyjątkowo $\mathrm{w}$ województwie wielkopolskim w pasie graniczącym z województwem łódzkim zanotowano od 1810 do 1916 roku nazwiska Firaza, Fieraza, Firaz czy Firazińska. Wymienione źródła nie podają $\mathrm{z}$ tego okresu nazwiska Firaga.

$\mathrm{Z}$ danych genealogicznych wynikałoby zatem, że nazwisko Firadza ekspandowało w XX wieku na inne tereny właśnie z obszaru pow. kutnowskiego i/lub łęczyckiego ${ }^{3}$.

Nazwisko Firadza niewątpliwie należy do rzadkich. W Słowniku nazwisk współcześnie w Polsce używanych Kazimierza Rymuta ${ }^{4}$ zanotowano 77 nosicieli tego nazwiska ( 23 osoby w woj. koszalińskim ${ }^{5}, 20$ w płockim, 13 w łódzkim, $13 \mathrm{w}$ wałbrzyskim, 2 w legnickim, 2 w rzeszowskim, 2 we wrocławskim, 1 w konińskim, 1 w szczecińskim).

W Słowniku nazwisk używanych $w$ Polsce na początku XXI wieku Kazimierza Rymuta ${ }^{6}$ według danych PESEL z 2002 roku poświadczono, że nazwisko to nosiły 72 osoby ( 38 kobiet i 34 mężczyzn). Z bazy danych Ministerstwa Cyfryzacji na dzień 22 stycznia 2020 roku nazwisko Firadza nosi 35 mężczyzn i 40 kobiet $^{7}$.

Pod względem geograficznym omawiane nazwisko grupuje się wspólcześnie głównie w Polsce północno-zachodniej (woj. zachodniopomorskie), centralnej (woj. łódzkie) i południowo-zachodniej (woj. dolnośląskie), por. tabela 1 .

Parafia ta położona jest około $15 \mathrm{~km}$ od parafii w Krośniewicach.

Potwierdza ten fakt rodzina męża: rodzeństwo pradziadka męża osiedliło się w woj. zachodniopomorskim, zaś brat męża $\mathrm{z}$ rodziną - w woj. mazowieckim.

$4 \quad$ K. Rymut, Stownik nazwisk wspótcześnie w Polsce używanych, t. 3: E-G, Kraków 1993.

5 Obowiązywał wówczas inny podział administracyjny kraju (na 49 województw).

$6 \quad$ K. Rymut, Slownik nazwisk używanych w Polsce na początku XXI wieku, Kraków 2003.

7 https://dane.gov.pl./dataset/1681,nazwiska-osob-zyjacych-wystepujace-w-rejestrze-pesel, dostęp: 17.02.2020. 
Tabela 1. Rozkład występowania nazwiska Firadza w powiatach w Polsce

\begin{tabular}{|l|c|c|}
\hline \multicolumn{1}{|c|}{ Województwo } & Powiat & $\begin{array}{c}\text { Liczba osób o nazwisku Firadza } \\
\text { (kobiety/mężczyźni) }\end{array}$ \\
\hline \multirow{2}{*}{ zachodniopomorskie } & pow. koszaliński & $23(12 / 11)$ \\
& m. Koszalin & $4(2 / 2)$ \\
\hline \multirow{2}{*}{ łódzkie } & pow. kutnowski & $14(8 / 6)$ \\
& m. Łódź & $11(6 / 5)$ \\
\hline \multirow{2}{*}{ dolnośląskie } & pow. dzierżoniowski & $5(3 / 2)$ \\
& pow. polkowicki & $2(1 / 1)$ \\
& m. Wałbrzych & $3(2 / 1)$ \\
\hline mazowieckie & m. Wrocław & $2(0 / 2)$ \\
\hline podkarpackie & pow. wołomiński & $4(1 / 3)$ \\
\hline
\end{tabular}

Źródło: http://nlp.actaforte.pl:8080/Nomina/Ndistr?nazwisko=Firadza (dostęp: 10.05.2019) ${ }^{8}$.

RDZEŃ FIER, FIR W NAZWISKACH I APELATYWACH

Omawiane nazwisko jest bez wątpienia obcobrzmiące. Obecność obcobrzmiących nazwisk w Polsce nie dziwi, gdyż „na rozwój polskiego systemu nazewniczego - zarówno nazw geograficznych, jak i osobowych - miały wpływ różne nacje, które z racji sąsiedztwa, uwarunkowań historycznych, polityczno-społecznych i gospodarczych odcisnęły piętno na dziejach naszej państwowości i języka"".

Kazimierz Rymut pisze, z jednej strony, o germańskiej proweniencji nazwisk z rdzeniem fier-/fir-, por. zapisy w słowniku Kazimierza Rymuta: $\mathrm{Na}$ zwiska Polaków. Stownik historyczno-etymologiczny ${ }^{10}$, z drugiej - wskazuje na gwarowe podstawy fira, firka. Nazwiska z rdzeniem fier-/fir- wywodzi Rymut od niemieckiej nazwy osobowej Fier, Fir, a te od apelatywu vier 'cztery', na Kresach Wschodnich też od Olefir, Olefier: Fiera 1687, Fier-asi+ewicz, Fier-c+ek, Fier-cz+yk, Fier-cz+yński, Fier+ek, Fier-och, Fier-osi+ewicz, Fier+ski, Fier+us, Fier+uś, Fier+ut, Fier+uta; Fierk, Fierka, Fierke, Fierkiewicz, Fierko 1475 (KrW), Fierk-owicz 1680, Fierk-us; Fir, Fira 1769 (od gw.

8 Dane pochodzą z publikacji: K. Rymut, Stownik nazwisk używanych w Polsce na początku XXI wieku, opartej na bazie PESEL z 2002 r.

9 M. Jaracz, Bydgoskie nazwiska pochodzenia niemieckiego. Rekonesans badawczy, „Onomastica" 2012, t. 56, s. 105.

10 K. Rymut, Nazwiska Polaków. Stownik historyczno-etymologiczny, t. 1: A-K, Kraków 1999, vs. Fier. 
fira 'kobieta rozpustna'), Fir-ak, Fir-as, Fir-as+ewicz, Fir-asz, Fir-asz+ewicz, Fir-asz+yński, Fir-aś, Fir-ek 1631 (por. też gw. firka 'ptaszek podobny do sikory; drobnostka'), Fir-esi+ewicz, Fir-es+ko, Fir-ewicz, Firo, Fir-och, Fir-ok., Fir-oń-cz+yk, Fir-osz, Fir-owicz, Fir-owski, Fir-us, Fir-uś, Fir-ut, Fir-uta, Fir-uz+ek, Fir-ysi+uk; Firka 1488 (od firka), Firke, Firki-ewicz, Firko 1476 $(\mathrm{KrW})$, Firk-owicz, Firk-owski, Firk-us.

Kazimierz Rymut podkreśla szczególną rolę żywiołu i języka niemieckiego: „Bardzo długo na nasze nazwy osobowe oddziaływało nazewnictwo niemieckie. Najwcześniej ten wpływ uwidocznił się na Pomorzu, trochę później na Śląsku i w zachodniej Wielkopolsce. W dokumentach pomorskich już w XI wieku występują niemieckie nazwy osobowe, na Śląsku częściej występują w XIII wieku. Na zachodnich rubieżach późniejszego państwa polskiego nazwiska niemieckie przyniosła kolonizacja niemiecka trwająca całe wieki. Wewnątrz kraju silne wpływy niemieckie wystąpiły w większych miastach, zwłaszcza w Krakowie i we Lwowie, a także w Toruniu, Poznaniu i trochę później w Warszawie. W księgach miejskich, poczynając od wieku XIV, pojawiają się bardzo liczne nazwy osobowe. Silny wpływ żywiołu niemieckiego w miastach polskich w wiekach średnich maleje w wieku XVI" "11.

Jeśli chodzi o inne źródła onomastyczne, to nazwy Fierka, Firko, Fierko notuje Stownik staropolskich nazw osobowych pod redakcją Witolda Taszyckiego $^{12}$, por.

Firka (?): Provido Iohanni Firka de Lobznicza 1488 ARP II 1491.

Firko, Fierko 1. Firko: Providus Firko, actor, homo regius de Oszko 1476 AGZ XVII 1223 (cf. infra cap. 2); Laborios(i)... Vasco Firko...kmethonis de Oszko 1477 AGZ XVII 1318. 2. Fierko: Laboriosus... Vaschko Fierko ...homo(-) de Oschko 1475 AGZ XVII 1204 (cf. supra cap. 1); Kmethon(em)... de Buchovicze Fyerko 1499 AGZ XVII 3130.

Aleksandra Cieślikowa w pracy Staropolskie odapelatywne nazwy osobo$w e^{13}$ przytacza nazwisko Firka, por.

Firka 1488 Wlkp; okr. II 1; op; - firka 'moneta miedziana' SW.

W Antroponimii Polski od końca XVI do końca XVIII wieku ${ }^{14}$ zanotowano następujące nazwiska z rdzeniem fier-/fir-: Fir, Fier, Fira, Fiera, Fierzyna, Firówna, Firek, Fierek, Firkowa, Firkówna, Firka, por.

\section{Fir, Fier}

1. SSNO: brak; AntrP: Fier 1633; SNW: Fir (153), Fier (22).

\footnotetext{
$11 \quad$ K. Rymut, Nazwiska Polaków..., s. LXVI.

12 W. Taszycki (red.), Stownik staropolskich nazw osobowych, t. 2: E-Ki, Wrocław 19681970.

13 A. Cieślikowa, Staropolskie odapelatywne nazwy osobowe: proces animizacji, Wrocław 1990, s. 37.

14 Eadem (red.), Antroponimia Polski od końca XVI do końca XVIII wieku. Wybór artykułów hastowych oraz wykazy nazwisk wraz z chronologia i geografia, t. 1: A-G, Kraków 2007.
} 
2. nom. sg. Fir 1695, Fier 1633.

3. Fir XVII: Młp (InKr).

Fier XVII: Młp. (InKr).

4. Druga pozycja: W Jemielnie ... zagrodnik(-) osiadł(y): Wojciech Fier 1633 InKr 43; Mostkowice ... zagrodnik Jakub Fir 1695 InKr 373.

$5 . \mathrm{cm}$.

6. Rzadkie.

7. Od niem. n.os. Fier, Fir, a ta od ap. niem. fier, vier (od fr. fier) 'dumny, wytworny, piękny' lub od vier 'cztery', ewentualnie od niem. ap. vir 'bagno, trzęsawisko', por. Fi(e)r NG, Fier Rym NP; lub od ap. pol. fir, por. gw. z południa Polski fir 'dowódca', fir, fir 'wykrzyknik do ptaków' lub fira 'kobieta rozpustna', por. Firyn, Fir, Fira Breza. Zmiana fonetyczna: $-i->-e$ - przed - $r$ -

\section{Fira, Fiera}

1. SSNO: brak; AntrP: Fiera 1610; SNW: Fira (542), Fiera (7).

2. nom. sg. Fiera (1610); gen. sg. Fiera (!) 1703; dat. sg. Fira (!) 1624.

3. Fira XVII: Wlkp (NByd).

4. Druga pozycja: Provido Gasparo Fira, subdito de villa Żołędowo 1624 NByd 118; laboriosus Mathia Fiera et Anna In Rozbark 1687 BoBy 114; Andreas, Mathaei Fiera de Rozbarg filius 1703 ibid; Jacobus Fiera ex suburbia 1709 ibid; laboriosi Mathaei Fiera et Catharinae ex Rozbark 1713 ibid. 349.

Trzecia pozycja: Nicolaus Ludovici Fiera, Cracoviensis 1610 KsKrak

Rodzinność: nazwisko męskie jest podstawą form żeńskich z suf. $-y n a$, -ówna, por. niżej

5. op, cm, cl.

6. Rzadkie

7. Fira, Fiera, od ap. fira 'kobieta rozpustna', przen. 'człowiek małej wartości', por. fira SW lub Fir-a, Fier-a - powstałe w efekcie derywacji paradygmatycznej od n.os. Fir, Fier, a te od ap. niem. fier, vier 'dumny, wytworny, piękny' lub od niem. vier 'cztery', por. Fir, także: Fi(e)r NG, Fier RymNP, Firyn, Fir, Fira Breza.

Fierzyna fem.

1. SSNO: brak, AntrP: Fierzyna 1769.

2. nom. sg. Fierzyna 1769.

3. XVIII: Wlkp (MączŁ).

4. Druga pozycja: Haeva Ferzyna (!) de civ(itate) Łodz 1769 MączŁ 60.

5. op.

6. Bardzo rzadkie.

7. Fierz-yna, utworzone za pomocą formantu -yna // -ina od n. os. Fiera, por. Fira.

Firówna fem.

1. SSNO: brak; AntrP: Firówna 1769. 
2. nom. sg. Firówna 1769.

3. XVIII: Wlkp (MączŁ).

4. Druga pozycja: Marianna Firowna de Łodz 1769 MączŁ; Marianna Firuwna de Łodz 1776 ibid.

5. op.

6. Bardzo rzadkie.

7. Fir-ówna, nazwisko utworzone od n. os. Fir lub Fira, por. Fir i Fira.

Firek, Fierek

1. SSNO: Firka 1488, Firko 1476, Fierko 1475; AntrP: Firek 1621; SNW: Firek (1712), Fierek (1797).

2. nom. sg. Firek 1621, Fierek 1687.

gen. pl. rel. Firków 1631, 1771.

3. Firek XVII: Młp (BuNT, InKr), Śl (NCiesz, NJabł); XVIII: Młp (BuNT, $\mathrm{KIRu}$, LuKrak).

Fierek XVII: Młp (BuNT)

4. Jedno określenie: Firek 1621 NCiesz 135; Firek 1631 BuNT I 100; Ochojno ... (kmieć) - Firek robi dni 51671 InKr 124; Firek 1678 NCiesz 135; Fierek 1687 BuNT I 100; Firek 1786 ibid.; Fierek 1790 ibid.

Druga pozycja: Nicolaus Firek 1699, 1702, 1703, 1704 NJabł 54; Lab(oriosi) Josephi et Petronilla Firkow 1771 KlRu 104; Osiadłość wsi Lgoty ... Mateusz Firek 1789 LuKrak I 244.

Funkcja relacyjna: Stanislai Fabri, Firkow zięć 1631 BuNT I 101.

Rodzinność: nazwisko męskie jest podstawą form żeńskich z suf. -owa, -ówna oraz -ka lub formantem paradygmatycznym - $a$, por. niżej.

$5 . \mathrm{cm}$.

6. Rzadkie, głównie w Małopolsce i na Śląsku.

7. Firek, Fierek, może pochodzić od niem. ap. Viereck lub od gw. firek 'lekkoduch' (por. gw. firka 'ptaszek podobny do sikory' lub 'drobna moneta wartości czterech groszy', a to od niem. vier „,cztery'), lub Fir-ek, Fier-ek nazwisko $\mathrm{z}$ formantem -ek utworzone od podstawy Fir, Fier, por. Fir, także: Firka Nap, Fi(e)r NG, Fier RymSEN, Firyn, Fir, Fira Breza.

Firkowa fem.

1. SSNO: brak; AntrP: Firkowa 1692.

2. nom. sg. Firkowa 1692.

3. XVII: Śl (NJabł).

4. Druga pozycja: Catharina Firkowa 1692 NJabł 55.

5. Status niejasny, prawdopodobnie $\mathrm{cm}$.

6. Bardzo rzadkie.

7. Firk-owa, por. Firek.

Firkówna fem.

1. SSNO: brak; AntrP: Firkówna 1662.

2. nom. sg. Firkówna 1662. 
3. XVII: Młp (KIRu); XVIII: Młp (KIRu).

4. Druga pozycja: Haeduigis Firkowna z Nielepic 1662 KlRu 104; Sophia Firkowna z Siedlec 1751 ibid.

5. $\mathrm{cm}$.

6. Bardzo rzadkie.

7. Firk-ówna, por. Firek.

Firka fem.

1. SSNO: brak; AntrP: Firka 1663.

2. nom. sg. Firka 1663.

3. XVII: Młp (KIRu).

4. Druga pozycja: Haeduigis Firka z Rudawy 1663 KIRu 104.

5. $\mathrm{cm}$.

6. Bardzo rzadkie.

7. Fir-ka, wg KIRu: od nazwiska męskiego Firek $\mathrm{z}$ formantem - $a$, lub Fir-ka, od Fir lub Fira z formantem -ka, por. Firek, Fir, Fira.

Żadnej nazwy własnej z rdzeniem fier-/fir- nie notuje Witold Taszycki w pracy Najdawniejsze polskie imiona osobowe ${ }^{15}$.

We współczesnych monografiach i słownikach antroponimicznych ${ }^{16}$ odnajdujemy tylko nazwiska Fira czy Firka. Tak np. Katarzyna Skowronek w pracy Wspótczesne nazwisko polskie. Studium statystyczno-kognitywne przytacza wśród nazwisk motywowanych paradygmatycznie przez rzeczowniki pospolite i własne nazwisko Fira ${ }^{17}$.

Z kolei Lucyna Tomczak w Stowniku odapelatywnych nazwisk Polaków ${ }^{18}$ notuje nazwiska:

Fira od fira 1. gw. 'kobieta rozpustna'; 2. fir gw. 'dowódca' katowickie 9, krakowskie 1.

Firka od firka 1. przen. 'drobnostka'; 2. gw. 'ptaszek'; 3. gw. 'dziewczyna trzpiotowata'; 4. gw. 'przyrząd do kręcenia sznurów' gdańskie 1, kieleckie 3, krakowskie 1.

Podsumowując dane ze źródeł onomastycznych, można zauważyć, że nazwisko Firadza nie pojawia się w nich do końca XVIII wieku. Nazwisko to występuje jedynie w Stowniku nazwisk współcześnie w Polsce używanych Kazimierza Rymuta ${ }^{19}$ oraz w Stowniku nazwisk użwanych $w$ Polsce na poczatku $X X I$ wieku tegoż autora ${ }^{20}$. Wydaje się zatem, że omawiane nazwisko pojawia

15 W. Taszycki, Najdawniejsze polskie imiona osobowe, Warszawa-Kraków-Lublin-ŁódźPoznań-Wilno-Zakopane 1925.

16 Biorę pod uwagę prace o zasięgu materiałowym ogólnopolskim.

17 K. Skowronek, Współczesne nazwisko polskie. Studium statystyczno-kognitywne, Kraków 2001, s. 128.

18 L. Tomczak, Stownik odapelatywnych nazwisk Polaków, Wrocław 2003.

19 K. Rymut, Stownik nazwisk wspótcześnie....

20 Idem, Stownik nazwisk używanych.... 
się dopiero w XIX wieku, na co wskazywałyby również dane Archiwum Państwowego w Łodzi.

Apelatywy fir, fira, firka notowane są w polszczyźnie zarówno historycznej, jak i współczesnej.

Stownik polszczyzny XVI wieku pod red. Marii Renaty Mayenowej ${ }^{21}$ notuje firkę < fierka w znaczeniu 'drobna moneta niemiecka równa 4 fenigom'.

Z kolei Elektroniczny słownik języka polskiego XVII i XVIII wieku (do $1772 \mathrm{roku})^{22}$ podaje hasło firka najwcześniej poświadczone w 1650 roku oraz 4 cytaty w korpusie barokowym, por. 1) wykupie jako swoje Szymonowi Karhowi.242. Zapis Walantego Firka z Nieledwie. - Przy tymże sadzie zupełnem stanąwszy [Księga sądowa państwa żywieckiego, powstała między 1681 a 1752 r., s. 99], 2) Nieledwie - Przy tymże sadzie zupełnem stanąwszy Walanty Firek z Nieledwie o polane. Która mu ociec z zymny przy [Księga sądowa państwa żywieckiego, powstała między 1681 a 1752 r., s. 99], 3) solisá vias, w garści u niego Asia, A firka, Europa, i Ocean, Ameryka, i wszystek [Francesco Andreini, Bohatyr straszny, 1965, s. 136], 4) mam/kiedy się odrodzą Od swych Przodków/za firkę i za prostych chłopów. Nie pomoże starożytne urodzenie [Krzysztof Opaliński, Satyry albo przestrogi do naprawy rządu i obyczajów w Polszcze, 1650, s. 98].

Stownik języka polskiego Samuela Bogumiła Lindego ${ }^{23}$ rejestruje apelatyw firka, por. Kiedy się odrodzą od swych wielkich przodków, Mam ich za firkę i prostych chłopów (Opal. Sat 107); Ona święta cnota, nie stoi za firkę, kiedy niema złota (Papr C.b).

Natomiast Stownik języka polskiego, tzw. warszawski ${ }^{24}$, notuje następujące przykłady: fir, fiyr 'dowódca' $<$ z niem. Führer $>$ oraz fira 'kobieta rozpustna' $<$ ? $>$.

Witold Doroszewski w Słowniku języka polskiego ${ }^{25}$, obejmującym materiał od II poł. XVIII wieku, przytacza nazwę firka daw. 1. 'moneta miedziana wartości czterech groszy', przen. a) 'drobnostka, bagatela, fraszka, głupstwo': Wzruszył ramionami, jakby chciał powiedzieć: - cóż to za firki prawicie mi waszmoście!...GOMUL. Miecz II, 129; b) 'o dziewczynie roztrzepanej, trzpiotowatej': Skaranie boże mieć pod okiem takie firki, co to pacierza nie umieją, o ścierce i o porządku nie pomyślą KORZ.J. cyt. $S W$; 2. 'gwarowa nazwa jednej z odmian sikory'; $<$ nm. vier $=$ cztery $>$.

\footnotetext{
$21 \quad$ M.R. Mayenowa (red.), Stownik polszczyzny XVI wieku, t. 7, Wrocław 1973.

22 W. Gruszczyński (red.), Elektroniczny słownik języka polskiego XVII i XVIII wieku (do 1772 roku), https://sxvii.pl, dostęp: 10.05.2019.

$23 \quad$ S.B. Linde, Stownik języka polskiego, t. 1, Lwów 1854.

24 J. Karłowicz, A. Kryński, W. Niedźwiedzki (red), Słownik języka polskiego, t. 1, Warszawa 1900.

25 W. Doroszewski (red.), Stownik języka polskiego, t. 2, Warszawa 1960.
} 
Aleksander Brückner w Stowniku etymologicznym języka polskiego ${ }^{26}$ podaje przykłady fira, fierka 'drobna moneta' (z niem. Vier 'cztery'), podkreślając, że nazwy zostały przeniesione na 'ludzi małej wartości', por. włos. ferlino.

Nazw fir, fira itp. nie notują: Stownik staropolski pod red. Stanisława Urbańczyka $^{27}$ czy Słownik etymologiczny języka polskiego Franciszka Sławskiego ${ }^{28}$.

W słowniku współczesnego języka polskiego odnajdujemy jedynie nazwę firka w następujących znaczeniach, por. firka 1 . 'staropolska moneta miedziana', 2. daw. 'rzecz lub osoba bez znaczenia'"29.

Również polskim gwarom znane są słowa fir, fira, firka, por.

Stownik gwar polskich Jana Karłowicza ${ }^{30}$ :

Fir w zagadce zamiast ser. Zb. I, 129, n 28. „Cyź ta firy (baby) ślepe były, Coś ta nam ją ocepiły?” Kal. I, 171, n 175, zwr. 2. „Śtery firy u śtafiry” (ma to znaczyć cztery nogi u zająca K.) Cisz. I, 263, n 209

Fir = 'dowódca' Zb. XIV, 5 „Dostał fiyrem” Zb. VII, 11, Fir = podoficer, Rozpr. XX, 427

Fir, fir, fir: „Skowronek ... o kolędę ...prosi: 'fir,f. f.', tak prosi” Krak. I, 241, n 53, zwr. 5. Fir, fir, fir = 'przywoływanie wróbli' Cen.78, Fir, fir = 'naśladowanie szelestu lotu ptaków’ Ram. 37. „Wróble taką pomiędzy sobą prowadzą rozmowę: ‘Firlip, fir, fir, Wiesz ty Księzy jęczmień?” Zb. XI, 46. „Kedy uone (zmory) jadą na kole od kary, to uone tak kwiczą: firlut, fir" Nadm. 116

Fira $=$ rozpustna kobieta Udz.

Firka $=$ 'przyrząd do kręcenia sznurów na sieci' Prac. (od Mąkolna, w Kaliskiem)

Firka $=$ ptaszek podobny do sikory Ust. z Zakopanego.

Stownik gwar polskich $\mathrm{PAN}^{31}$ :

I. Fir 'dowódca': Żołnierze śli tedy na maniebry (manewry), w drodze fir [...] im umar i tu go pochowali, znosząc ziemie na sablach dęb Zb XIV 5; pd ok. Chrzanowa MPKJ VII 327; 'plutonowy w dawnym wojsku austriackim': Jak go wzieni do wojska [...] pisze ten syn do ojca, że jest frajtrem ['starszym strzelcem']. [...] Za kilka miesięcy pisze on , że został kapralem. [...] I znowu on pisze, że jest firem ok. Łańcuta ME VI 395; n-tar MPKJ I 70; myślen Zb VII 11; niz RWF XX 427

II. Fir zag. 'o serze': Nad fimerami pod literami mam dwa mamra i półtora fira (Nad świniami pod liściem ukryte mam dwie kukiełki i 1 1 $\frac{1}{2}$ sera) $n$-tar Zb I 129
A. Brückner, Stownik etymologiczny języka polskiego, Warszawa 1985.
S. Urbańczyk (red.), Stownik staropolski, t. 2, Wrocław 1956-1959.
F. Sławski, Słownik etymologiczny języka polskiego, t. 1, Kraków 1952-1956.
https://sjp.pwn.pl/sjp/firka;2557952.html, dostęp: 24.05.2019.
J. Karłowicz, Stownik gwar polskich, t. 2, Kraków 1901.
Stownik gwar polskich, t. 7, z. 1 (20), pod kierunkiem J. Okoniowej, Kraków 2005. 
III. Fir dźw.-naśl., powtórzone 'w naśladowaniu': a. 'szumu skrzydeł lecącego ptaka': wej LPW I 195; Kasz Ram 37; b. 'głosu skowronka': Skowronek jak dzwonek [...] o kolędę pięknie prosi: fir, fir, fir, tak prosi [pśn] ok. Krakowa Krak I 241

IV. Fir 'okrzyk oznaczający nagły ruch': wej S VII 69. W połączeniu: Fir, fir, fir 'okrzyk przywołujący [!] wróble': wej LPW I 188; SW I 746

Fira 1. 'o kobiecie': Cyśta firy (baby) ślepe były, cośta nam ją [panne młoda] ocepiły [pśn, żart] łas Kal I 171; [pśn, żart] łódz jw; 'rozpustnej': dęb K II 18; 2. zag. 'o nodze zająca': Pewien kawaler posłał pannie w prezencie zająca [...]. Posłaniec w drodze zjadł połowę zająca [...]. Panna [...] kawalerowi odpisała tak: „Śtery firy u śtafiry, cemu dwie?” olk Cisz I 262-3.

Ten sam słownik podaje również dwa czasowniki firać (się) i firać się, por.

Firać (się) 'pośredniczyć w czymś, prowadzić czyjeś sprawy, interesy': v'ele lat uon firał naše spravə Stup LPW I 188

Firać się 'zachowywać się, sprawować się': u sołdatów uon są firał lyk ['zawsze'] dobře Slup jw. ${ }^{32}$.

Ponieważ na omawianym obszarze (tj. Kutnowskie, Łęczyckie), z którego pochodzą najstarsze dane o nazwisku Firadza, nie są znane słowa fir oraz fira w przytaczanych przez słowniki znaczeniach, por. fir 1. 'dowódca', 2. 'wyraz dźwiękonaśladowczy' określający a) szum skrzydeł lecącego ptaka, b) głos skowronka, 3. 'okrzyk oznaczający nagły ruch' oraz fira 1. 'kobieta', 2. 'rozpustna kobieta', 3. 'drobna moneta', 4. przen. 'człowiek małej wartości', być może należałoby rozważyć też inną etymologię nazwiska Firadza.

$\mathrm{Na}$ szczególną uwagę zasługuje nazwa fier w języku holenderskim (niderlandzkim) oznaczająca 'dumny' w kontekście osadnictwa na obszarze Kutnowskiego i Łęczyckiego. Mianowicie w gm. Nowe Ostrowy (pow. kutnowski) wieś Wołodrza była w pewnym okresie typowo holenderską wsią, o czym świadczą dane kartograficzne zawarte w Topograficznej Karcie Królestwa Polskiego (zwanej też Mapą Kwatermistrzostwa), wydanej w 1843 roku (wieś nazywała się wówczas Wołodrze Holenderskie). O pobycie na tych terenach Holendrów świadczy też zachowana do dzisiaj w powiecie kutnowskim w gm. Strzelce nazwa wsi Holendry Strzeleckie. W Łęczyckiem w gminie Świnice Warckie część wsi Podgórze nosi nazwę Holendry. W odniesieniu do powiatu łęczyckiego źródła historyczne podają, że w gminie Grabów cmentarze ewangelickie są pozostałością po Olędrach ${ }^{33}$, których osadnictwu kres

\footnotetext{
32 Ibidem.

33 Olędrzy - pierwotnie osadnicy z Fryzji i Niderlandów, którzy w XVI-XVII wieku zakładali wsie w Prusach Królewskich, wzdłuż Wisły i jej dopływów, na Kujawach, Mazowszu i w Wielkopolsce. W późniejszym okresie (aż do poł. XIX w.) mianem olędrów określano osadników różnej narodowości, głównie Polaków i Niemców, którzy korzystali z pewnych przywilejów wynikających z prawa stosowanego przez kolonistów fryzyjskich i niderlandzkich. Słowo olęder nie jest tożsame z osadnikiem holenderskim. Według dotychczasowych badań
} 
położyła II wojna światowa. Jako ciekawostkę można przytoczyć fakt, że w powiecie łęczyckim odnaleziono ślady szesnastu cmentarzy ewangelickich, z czego aż jedenaście znajduje się w gminie Grabów, skąd pochodzą najstarsze dane o nazwisku Firaza (por. Jan Firaza ur. 1812 r., brak nr aktu urodzenia, czy Stanisław Firaza ur. 1817 r. nr aktu 59) ${ }^{34}$.

Być może zatem na tym obszarze nazwisko Firadza należy łączyć z podstawą fier 'dumny', por. też niem. fier, vier 'dumny, wytworny, piękny'.

$\mathrm{Z}$ jednej strony nazwisko Firadza należy do antroponimów o małej frekwencji ${ }^{35}$, z drugiej - źródła podają kilkadziesiąt nazwisk z rdzeniem fier-, fir. Współcześnie zanotowałam m.in. następujące nazwiska zawierające rdzeń fier-, fir-, für-/fur-:

Nazwiska z fier-: Fier, Fiera, Fieraza, Fierek, Fierich, Fierk, Fierka, Fierke, Fierna, Fieroch, Fierska, Fierus, Fieruś, Fierut, Fieruta.

Nazwiska z fir-: Fir, Fira, Firadza, Firaga, Firago, Firak, Firan, Firanek, Firas, Firasz, Firaś, Firaza, Firczuk, Firczyk, Firecki, Firek, Firer, Firik, Firin, Firka, Firke, Firko, Firkus, Firo, Firoch, Firok, Firosz, Firus, Firuś, Firut, Firuta, Firyk, Firyn.

Nazwiska z für-/fur-: Fuhr, Führa, Fuhrer, Führer, Fuhrich ${ }^{36}$.

Tak jak nie do końca jasna jest etymologia rdzenia w nazwisku Firadza, tak i wątpliwości budzi sufiks -(a)dza.

Głoska $d z$ w języku polskim jest kontynuacją: 1) prasłowiańskiego $d z$, które alternuje z g, ż, np. noga, odnoże, nodze (psł. *noga, *otъnožbje, *nozě), 2) prasłowiańskiego $d j$, które alternuje $\mathrm{z} d \mathrm{i} d$ ', np. widać, widzieć, widze (psł. *vidati, *vidéti, *vidjo). Poza tym mamy jeszcze w polszczyźnie nowe $d z$, które powstało spontanicznie z dawniejszego $z$, por. stp. smarze, dziś smardze, stp. barzo, dziś bardzo, ogsłow. zvon, zvono odpowiada polskim $d z w o n, d z w o n o^{37}$.

Ponieważ żadne źródła nie podają sufiksu -(a)dza, wydawać by się zatem mogło, że nazwisko Firadza utworzone zostało bądź sufiksem -(a)ga (pochodzącym z psł. *-aga ${ }^{38}$ ), bądź sufiksem $-(a) d a$ (powstały w epoce psł.

w latach 1527/1547 do 1864 na obszarze I Rzeczypospolitej (następnie w trzech zaborach) powstało co najmniej 1700 osad olęderskich, z czego w przynajmniej 300 przypadkach osadnikami byli etniczni Holendrzy. Ślady po osadnictwie widoczne są do dziś, zarówno w architekturze wiejskiej, układach przestrzennych wsi, jak i w nazwach miejscowości (por. Holendry, Olędry, Olendry itp.), por. Z. Chodyła, Najstarsze dzieje osad olęderskich w okolicach Nekli w latach 1749-1793, Nekla 2005; A. Pabian, M. Targowski (red.), Olędrzy. Osadnicy znad Wisty. Sąsiedzi bliscy i obcy, Toruń 2016.

34 www.cmentarzeewangelickie-lodzkie.pl; https://genealogia.com.pl/genealogia dostęp: 24.05.2019, 30.07.2020.

35 Jak zresztą większość (a może i wszystkie) nazwiska z rdzeniem fir-, fier-.

36 https://genealogia.com.pl/genealogia/nazwiska/nazwiska_f.htm, dostęp: 24.05.2019.

37 J. Łoś, Gramatyka polska, cz. I, Gtosownia historyczna, Lwów-Warszawa-Kraków 1922, s. 148 .

38 F. Sławski (red.), Stownik prasłowiański, t. 1, $A-B$, Wrocław 1974, s. 65. 
z połączenia przyrostka $*-d a$ z wygłosową samogłoską tematyczną ${ }^{*}-\mathrm{b}^{-}{ }^{39}$ ), w którym to sufiksie dokonała się omówiona wyżej, ale notowana także we współczesnej polszczyźnie wymiana morfonologiczna: a) welarnej twardej $g$ na funkcjonalnie miękką $d z$, por. Firaga: Firadza tak jak: warga: wardze, droga: drodze, kolega: koledze; b) wymiana zębowej twardej $d$ na funkcjonalnie miękką $d z$, por. Firada: Firadza tak jak: jadty: jedza, chłodny: chłodza, gładki: gładza ${ }^{40}$. W żadnych źródłach nie spotkałam jednak nazwiska Firada. Źródła nie podają też z omawianego okresu (tj. XIX wieku) nazwiska Firaga.

W źródłach archiwalnych istnieją natomiast, jak wspomniałam wyżej, nazwiska Firaza, Fieraza (1810 r.) oraz Firadza (1852 r.). Być może świadczy to o tym, że -(a)dza powstało z -aza na wzór bar-zo, dziś bardzo itp. Co ciekawe, Katarzyna Skowronek, omawiając współczesne nazwiska polskie, nawet wśród bardzo rzadkich typów budowy polskiego nazwiska nie wymienia sufiksów -aza czy - $a d z a^{41}$.

Jeśli chodzi o nazwiska z podstawowym -z- w części sufiksalnej, to wśród staropolskich apelatywów antroponimicznych wymienia się tylko jednostkowy derywat $\mathrm{z}$ sufiksem -ęza ${ }^{42}$. W antroponimii nie zostały odnotowane wśród imion skróconych; nielicznie reprezentowane są wśród nazwisk współczesnych. Analiza materiału przeprowadzona przez Katarzynę Skowronek sugeruje, że są to rzeczywiście niezwykle rzadkie typy słowotwórcze, reprezentowane na ogół przez jednostkowe antroponimy w obu zbiorach ${ }^{43}$.

Tymczasem kwerenda zasobów internetowych pokazała, że nazwisk na -aza może być w Polsce około 50, por.: Almaza, Bachaza, Baltaza, Bataza, Beraza, Bieraza, Boltaza, Celaza, Ceraza, Chraza, Cyraza, Dolaza, Fieraza, Firaza, Gałaza, Giermaza, Glogaza, Godraza, Gogłaza, Hałabaza, Kabaza, Kałaza, Kolaza, Komaza, Krałaza, Łabaza, Łamaza, Łobaza, Łochaza, Łohaza, Łomaza, Nykaza, Obłaza, Ogaza, Ogłaza, Oraza, Pilaza, Podraza, Powaza, Prykaza, Przekaza, Ramaza, Rogaza, Sawraza, Szmaza, Taraza, Tułaza, Tyraza, Zbaraza ${ }^{44}$, co nie zmienia faktu, że jest to rzadki typ nazwisk.

Można by, co prawda, pokusić się o refleksję, iż być może to błąd urzędnika spowodował, że zamiast Firaza pojawiła się postać z - adza, co zdarza się wcale nierzadko ${ }^{45}$. Ale skąd $\mathrm{w}$ takim razie inne nazwiska na -adza, co prawda

\footnotetext{
$39 \quad$ Ibidem, s. 63.

$40 \quad$ J. Strutyński, Gramatyka polska, Kraków 1997, s. 152-153.

${ }^{41} \quad$ K. Skowronek, op. cit., s. 138, 166.

42 A. Cieślikowa, Staropolskie odapelatywne nazwy osobowe: proces onimizacji, Wrocław 1990, s. 166.

$43 \quad$ K. Skowronek, op.cit., s. 161.

44 https://genealogia.com.pl/genealogia/nazwiska/nazwiska_f.htm, dostęp: 24.05.2019.

45 Np. dwa takie przypadki potwierdza rodzina męża. Bratowa dziadka mojego męża ma wpisane w dokumentach nazwisko Firaza, a dziadek męża osobiście prostował w dokumentach
} 
w niewielkiej liczbie, por. Firadza, Gaładza, Goładza, Gwiadza, Muradza, Niewadza, Osadza, Posadza, Przeradza, Sieradza, Stradza ${ }^{46}$.

Możliwe, że powstanie nazwiska z formantem - $a g a$, por. współcześnie notowane Firaza (Fieraza), Firadza, Firaga ${ }^{47}$, wiązać należy z poczuciem obcości/rzadkości formantów - $a d z a$ czy $-a z a^{48}$.

Interesujące jest to, że wśród nazwisk na -ada, -adza, -aga, -aza znajdziemy kilka takich, które tworzą antroponimy mające identyczną podstawę, a różniące się formantem, por.

- ada i - $a d z a$, por. Gałada // Gaładza, Posada // Posadza, Przerada // Przeradza, - ada, -adza i -aga, por. Sierada // Sieradza // Sieraga, -adza, -aga i -aza, por. Firadza // Firaga // Firaza ${ }^{49}$. Najprawdopodobniej te dziś odrębne nazwiska mogły być jeszcze w XIX wieku dawnymi wariantywnymi formami tego samego nazwiska. Zwraca na ten fakt uwagę m.in. Agnieszka Raszewska-Klimas w odniesieniu do nazwisk piotrkowian, podkreślając jednocześnie, iż „Z perspektywy onomastycznej można określić dziewiętnastowieczny status antroponimów jakklasy in statu nascendi, z postępującym procesem stabilizacji nazwiska" $" 50$.

Poza kilkoma nazwiskami na $-a d z a$ odnotowałam również 4 nazwiska zakończone na -adzy, por. Cyradzy, Osadzy (por. wyżej Osadza), Pasadzy, Posadzy (por. wyżej Posadza), a także kilka nazwisk na -adze: Brygadze, Gwaramadze, Macharadze, Mamaładze, Mgeładze-Arciuch, Szownadze, Talikadze, Ungiadze, Żupinadze ${ }^{51}$. Te ostatnie to nazwiska gruzińskie. W języku gruzińskim nadze znaczy 'gniazdo', dze 'syn', por. np. Eduard Szewardnadze - minister spraw zagranicznych Gruzji, prezydent Gruzji; Aleksander Czawczawadze - gruziński arystokrata, poeta, działacz społeczny, „ojciec gruzińskiego romantyzmu", Wato Arweladze - gruziński piłkarz grający w Koronie Kielce itd.

Być może nazwiska na -adza lub -adzy mają też jakiś pośredni związek z nazwiskami na -adze.

swoje nazwisko z Firaza na Firadza (na nazwisko Firadza miał rodzinne akty notarialne z roku 1907 oraz 1917).

46 https://genealogia.com.pl/genealogia/nazwiska/nazwiska_f.htm, dostęp: 24.05.2019.

$47 \mathrm{https} / /$ genealogia.com.pl/genealogia/nazwiska/nazwiska_f.htm, dostęp: 24.05.2019.

48 Od męża i jego matki wiem, że w okolicy nazywani byli (i cały czas są) Firagami.

49 https://genealogia.com.pl/genealogia/nazwiska/nazwiska_f.htm, dostęp: 24.05.2019.

50 A.Raszewska-Klimas, Wariantywność dziewiętnastowiecznych nazwisk piotrkowian, „Onomastica" 2015, t. 59, s. 177.

51 https://genealogia.com.pl/genealogia/nazwiska/nazwiska_f.htm, dostęp: 24.05.2019. 


\section{PODSUMOWANIE}

Do powstania bardzo dużego zbioru nazwisk o niewielkiej frekwencji, a do takich należy nazwisko Firadza, przyczyniły się procesy dywersyfikacyjne $^{52}$. Jest to nie tylko nazwisko o niskiej frekwencji, ale też niewątpliwie nazwisko trudne do jednoznacznej analizy semantyczno-słowotwórczej. Najprawdopodobniej nazwisko wywodzi się od holenderskiego fier 'dumny', por. też niem. fier, vier 'dumny, wytworny, piękny', a utworzone zostało sufiksem $-a z a$, który następnie przekształcił się $\mathrm{w}-a d z a$. Za taką etymologią przemawiają dane genealogiczne, historyczne i geograficzne.

Nie można jednak wykluczyć także innej etymologii, a mianowicie podstawy fir wywodzącej się z niem. Vier 'cztery' oraz 'dumny, wytworny, piękny' lub z niem. Vir 'bagno, trzęsawisko'. Tereny, z których pochodzą najstarsze zapisy omawianego nazwiska, są bowiem obszarami zamieszkiwanymi również przez osadników pochodzenia niemieckiego, co poświadczają dane historyczne ${ }^{53}$.

Najmniej prawdopodobne wydaje się pochodzenie nazwiska Firadza od gwarowych form fira 'kobieta rozpustna', firka 'ptaszek podobny do sikory, drobnostka' czy też , fir, fir 'wykrzyknik do ptaków', które na obszarze Kutnowskiego i Łęczyckiego nie są znane.

\section{BIBLIOGRAFIA}

Brückner Aleksander. 1985. Stownik etymologiczny języka polskiego. Warszawa: Wydawnictwo Wiedza Powszechna.

Bubak Józef. 1989. Pochodzenie polskiego nazwiska Uryga. „Onomastica” t. 33: 209-212.

Chodyła Zbigniew. 2005. Najstarsze dzieje osad olęderskich w okolicach Nekli w latach 1749-1793. Nekla.

Cieślikowa Aleksandra. 1990. Staropolskie odapelatywne nazwy osobowe: proces animizacji. Wrocław: Wydawnictwo Ossolineum.

Cieślikowa Aleksandra. Red. 2007. Antroponimia Polski od XVI do końca XVIII wieku. Wybór artykułów hastowych oraz wykazy nazwisk wraz z chronologia i geografia, t. 1: $A-G$. Kraków: Wydawnictwo Lexis.

Doroszewski Witold. Red. 1960. Słownik języka polskiego t. 2. Warszawa: Wydawnictwo Wiedza Powszechna.

Gruszczyński Włodzimierz. Red. Elektroniczny słownik języka polskiego XVII i XVIII wie$k u($ do 1772 roku). W: https://sxvii.pl [Dostęp 10.05.2019].

Jaracz Małgorzata. 2012. Bydgoskie nazwiska pochodzenia niemieckiego. Rekonesans badawczy. „Onomastica” t. 56: 105-116.

Karłowicz Jan. 1901. Słownik gwar polskich t. 2. Kraków: nakładem Akademii Umiejętności.

\footnotetext{
$52 \quad$ K. Skowronek, op. cit., s. 180.

53 K. P. Woźniak, Niemieckie osadnictwo wiejskie między Prosna a Pilica i Wista od lat 70. XVIII wieku do 1866 roku. Proces i jego interpretacje, Łódź 2013.
} 
Karłowicz Jan, Kryński Adam, Niedźwiedzki Władysław. Red. 1900. Słownik języka polskiego t. 1. Warszawa: wydano Nakładem prenumeratorów w drukarni E. Lubawskiego i S-ki.

Linde Samuel Bogumił. 1854. Stownik języka polskiego t. 1. Lwów: Wydawnictwo Ossolińskich.

Łoś Jan. 1922. Gramatyka polska, cz. I. Głosownia historyczna. Lwów-Warszawa-Kraków: Wydawnictwo Ossolińskich.

Mayenowa Renata Maria (red.). 1973. Stownik polszczyzny XVI wieku t. 7. Wrocław: Wydawnictwo Ossolineum, PAN.

Pabian Andrzej, Targowski Michał. Red. 2016. Olędrzy. Osadnicy znad Wisty. Sasiedzi bliscy $i$ obcy. Toruń: Wydawca Fundacja Inicjatyw Społecznych ANRO.

Raszewska-Klimas Agnieszka. 2015. Wariantywność dziewiętnastowiecznych nazwisk piotrkowian. „Onomastica” t. 59: 169-179.

Rymut Kazimierz. 1993. Słownik nazwisk wspótcześnie $w$ Polsce używanych t. 3: $E-G$. Kraków: Wydawnictwo Instytutu Języka Polskiego PAN.

Rymut Kazimierz. 1999. Nazwiska Polaków. Słownik historyczno-etymologiczny, t. 3: $A-K$. Kraków: Wydawnictwo Instytutu Języka Polskiego PAN.

Rymut Kazimierz. 2003. Słownik nazwisk używanych w Polsce na początku XXI wieku. Kraków: Wydawnictwo Instytutu Języka Polskiego PAN.

Skowronek Katarzyna. 2001. Wspótczesne nazwisko polskie. Studium statystyczno-kognitywne. Kraków: Wydawnictwo DWN.

Sławski Franciszek. 1952-1956. Słownik etymologiczny języka polskiego t. 1. Kraków: wydano nakładem Towarzystwa Miłośników Języka Polskiego.

Sławski Franciszek. Red. 1974. Słownik prasłowiański t. 1: A-B. Wrocław: Wydawnictwo Ossolineum.

Stownik gwar polskich. 2005 t. 7 z. 1 (20) pod kierunkiem Joanny Okoniowej. Kraków: Wydawnictwo PAN.

Strutyński Janusz. 1997. Gramatyka polska. Kraków: Wydawnictwo Tomasz Strutyński.

Taszycki Witold. 1925. Najdawniejsze polskie imiona osobowe. Warszawa-Kraków-LublinŁódź-Poznań-Wilno-Zakopane: wydano nakładem Polskiej Akademii Umiejętności.

Taszycki Witold. Red. 1968-1970. Stownik staropolskich nazw osobowych t. 2: E-Ki. Wrocław: Wydawnictwo Ossolineum.

Tomczak Lucyna. 2003. Słownik odapelatywnych nazwisk Polaków. Wrocław: Wydawnictwo Uniwersytetu Wrocławskiego.

Urbańczyk Stanisław. Red. 1956-1959. Stownik staropolski t. 2. Wrocław: Wydawnictwo Ossolineum, PAN.

Woźniak Krzysztof Paweł. 2013. Niemieckie osadnictwo wiejskie między Prosna a Pilica $i$ Wista od lat 70. XVIII wieku do 1866 roku. Proces i jego interpretacje. Łódź: Wydawnictwo Uniwersytetu Łódzkiego.

\section{NOTES ON THE SURNAME FIRADZA}

Summary. The paper deals with a rare, foreign sounding name Firadza which is difficult to explain clearly. The aim of the article is to present a chronological and geographical stratigraphy of the name and different opinions on its etymology. The surnamediscussed has not yet been the topic of onomastic analyses, neither anthroponomical ones.

Key words: onomastics, anthroponymy, name 


\section{КІЛЬКА ЗАУВАЖЕНЬ ДО ПРІЗВИЩА ФІРАДЗА}

Анотація. Статтю присвячено рідкісному прізвищу Фірадза, що звучить як іншомовне і не піддається однозначному поясненню. Мета статті - окреслити хронологічну та географічну стратиграфію прізвища, а також представити декілька різних підходів щодо його етимології. Аналізоване прізвище досі не було об'єктом ономастичних, зокрема антропонімічних, міркувань.

Ключові слова: ономастика, антропонімія, прізвище 